\title{
CORAL REEF CONDITION AND HARD CORAL (SCLERACTINIA) COMUNITY IN LOCAL MARINE CONSERVATION AREA, BENGKAYANG, WEST KALIMANTAN
}

\author{
Miftahul Huda1', Suwarno Hadisusanto², and Encus Widyatmoko ${ }^{3}$ \\ ${ }^{1}$ Faculty of Biology Universitas Gadjah Mada \\ ${ }^{2}$ Faculty of Biology Universitas Gadjah Mada \\ ${ }^{3}$ Research center of Technology Universitas Gadjah Mada
}

\begin{abstract}
Coral reef ecosystem has diverse shape and stunning beauty. It has high value on both ecological and economical aspect it has productivity greater than other marine life. Local Marine Conservation Area, Bengkayang, West Kalimantan (Lemukutan island, Penata Besar island, Penata Kecil island, Seluas island, Rahdayan island) has a high potential on coastal and marine natural resources especially coral reefs ecosystem. The study was purposed to determine the condition coral reef ecosystem and the diversity of hard corals (Scleractinia). Samples have been taking from 5-7 meters depth in every point using Line Intercept Transect method (LIT). The observation result from the coral reef in Local Marine Conservation Area showed as the followings varies from bad to good $(13.82-69.00 \%)$, but biotic components were found in each area that consist of sediment with percentage of $4.32-37.68 \%$ and the rock of $2.57-38.22 \%$. Hard coral community consists of 35 species including seven families. Genus Acropora as hard coral species is dominating the five islands. The damage of coral reefs that occurs in most of the study area is due to increased suspended material (sediments).
\end{abstract}

Key words: Coral reefs, Scleractinia, Acropora, LIT, Local Marine Conservation Area, Bengkayang, West Kalimantan.

\section{INTRODUCTION}

Coral reefs are the marine ecosystem with diverse forms and dazzling beauty, ecologi$\mathrm{cal}$ and economic value that high. In addition to acting as coastal protection from waves and current waves strong, coral reefs also has ecological value as habitat, where looking for food, shelter care and grew up, as well as spawning sites for variety of marine life. Economic value of coral reefs that stand out are as place of capture various types of marine life and the consumption of various types of ornamental fish, pharmaceutical raw materials, and as a tourist and recreational areas Interesting (Dahuri, 2003).

Coral reef ecosystems are ecosystems that have value important, because the coral reefs have a high level of productivity than any other marine ecosystem. High diversity of marine life sala only coral reefs as a source of food and medicine. Hard corals (hard corals) is a place of life, and seek shelter eaten by many types of other organisms such as crustaceans, molluscs, Echinodermata, Polychaeta, Porifera and Coelenterata. Coral reefs have a factor important in the preservation of marine ecosystems. Resource utilization on coral reefs should be done in a way that is not destructive. If damage occurs, it will take a long time to return as before. Human activities threaten the currently estimated $88 \%$ of reefs reefs in Southeast Asia (Indonesia and the Philippines have $77 \%$ of the total entire coral reef), threatens biological and economic value for the community. Approximately $50 \%$ of coral reefs are threatened, are at the level ofketera ncaman a high or very high. Only $12 \%$ of those are at a low level threat (Burke et al., 2001). 
Tropical areas and consists of many islands, Indonesia many found the sea with coral reef ecosystems. Conservation Areas Sea Area (KKLD) and surrounding island Lemukutan located in District Sungai Raya Islands, Bengkayang, West Kalimantan Province. This area also has the potential of natural resources and coastal seas especially coral reefs, which have the economic outlook is able to to encourage the growth and development of settlements around the region (DKP West Kalimantan, 2004).

\section{MATERIALS AND METHODS}

\section{Time and Location Research}

This study was conducted on 12 to 19 June 2012, with a time of 09:00-11:00 pm. and 13:30 to 15:00 pm. in Aquatic Marine Conservation Area, Bengkayang district, West Kalimantan on the coordinate 00.33 '.00 'S - 00.50 '.81 "N and 108 o.39' .00" BB - 109 0.04 '.76 "longitude. Data retrieval from Coral reef dives conducted at ten stations, the station of Lemukutan 1, Lemukutan 2, Lemukutan Cave, Lemukutan 3, Lemukutan 4, Stylists 1 large, 1 small Stylists, Covering an area of 1, Rahdayan 1, and 2 Rahdayan

\section{How it Works}

The method used in this study is the "Manta Tow Survey" menyeluruhdan to observe directly on the benthic community exist on coral reefs, including coral reefs whereas to obtain data on coral cover at each station used method LIT "Line Intercept Transect" (English et al., 1994).

The steps performed in conducting this study is: Location Determination, Making Line Intercept Transect length (50meter), Coral Reef Data Collection, Sampling Coral, Measurement of environmental parameters and calculating the data using the program If5_2 COREMAP-LIPI.

\section{RESULTS AND DISCUSSION \\ Coral Reef Health Conditions}

Observation of the condition of coral reefs in the waters carried Region Marine Conservation Area (KKLD) Lemukutan Island and surrounding areas. Location 5 study of the island into the edge of the reef type (fringing reef), because of the 10 point sampling locations found in coral cover depth of 5-7 meters. The results of the data found that in general the average conditions coral reefs in the study site quite varied, between burukbaik (13.82\% $69.00 \%$ ). There are two staisun with coral reefs damaged. The condition of coral reefs in each location dives as observation stations in the region and Lemukutan Island surrounding can be seen in Figure 9.

At all study sites categorized reef condition varied from bad to good. Average coral cover which is under 50\%. Live coral cover (Acropora and non-Acropora) were highest in Small stylist station is $69.00 \%$ at a depth of 6 meters and $55.16 \%$ in Great stylist station at a depth of 6 meters, while the lowest in the Covering an area of the station is $13.82 \%$ at a depth of 7 meters and $24.06 \%$ at station Rahdayan 2 at a depth of 5 meters. Live coral cover is low making productivity on small coral reef ecosystems. Low live coral makes recycling nutrients on the environment also declined. Symbiosis with the coral animals zooxanthellae, 
plays an important role in nutrient cycling processes. Zooxanthellae perform photosynthesis which will produce oxygen, energy and organic matter other. Coral animals provide the elements needed zooxanthellae to photosynthesize like $\mathrm{CO} 2, \mathrm{~N}$, and phosphorus. Live coral is also a source of food for some marine life such as sea stars among the thorny (Achanthaster sp.) That eat coral genus Poccillopora. At least nutrition contained in the reef cause marine life seeking eating at this place will be reduced, including the types of economic fish. Case The effect on the biodiversity of coral reef ecosystems.

In figure 9 it can be seen that each study site found coral dead (dead scleractinia) ranged from 1.68 to $6.70 \%$. One of the causes coral mortality is the use of cyanide to capture fish. Coral potash affected will experience bleaching (whitening) is colored coral white as zooxanthellae present in animal tissues of dead coral. Absence of zooxanthellae from the coral animal tissue can cause loses its energy source. Sediment can cover coral polyps so clogging food acquisition structure and disrupt the growth process. At the station location Rahdayan 2 reached $6.70 \%$ which may cause the time coral animals will die. Corals will experience death likely caused by potash, currents, sedimentation and big waves (Storm). Flow is one of the factors that brought the material suspended in sea and surface runoff occurs from land or river with locations research which is not far from the island of Borneo. Geographically Island Borneo lies to the northwest on the east side distance range of $25 \mathrm{~km}$. Location Lemukutan and surrounding islands are located in the west of the island of Borneo allows the waters affected by the season, including the movement of currents. At sampling time the highest abiotic factors the sediment (silt) and rock (rock). In June these waters have experiencing bad weather. Proved almost all stations found closure sedimentation, because at the time the study for 2 weeks turbidity occurs continuously both in the morning and afternoon. High turbidity causing a bit of research that is experiencing problems at the time of observation because the visibility is only 2-3 meters, but the closure is dominant highest corals (lifeform). Coral reefs in the island Lemukutan and the surrounding area has been degraded due to material suspended that happens every year during the monsoon, western or in May to August, because fishermen do not catch fish because of bad weather.Reef survey results conducted show that percentage of hard corals, which have long dead and covered with algae (Dead Coral with Algae-DCA) found relatively high at all stations observations. Many factors may be the cause of death of coral this stone and then formed DCA, one of which is the 6 high sedimentation coming from mainland borne by currents.

This follows in Table 5 the calculation of the average transition coral reef cover in KKLD at each observation station. Table 5 showed average transition cover on coral reefs by Lemukutan Island research station and its surroundings. Based on table 5 it can be seen in percent coral cover based form of his life. Acropora can spread well on the reef flats and slope. According Suharsono (1996) forming the main component of reef Acropora corals are found in almost all locations of coral reefs, then study the condition of coral reef ecosystems are divided into categories Acropora and non-Acropora. Based on table 5 Acropora is present in all stations either on depth of 5-7 meters, except at station 3 life forms Acropora is the Acropora branches found form (branching), Acropora table form 7 (Tabulate) and Acropora menjari forms (digitate). Data can be viewed not much Acropora encountered with menjari form, only at station $5(0.58 \%)$, the Station $8(1.74 \%)$ and at station $10(0.68 \%)$. This marks 
an menjari thicker than the compact form branched or cause slower growth. In general category encountered Acropora shaped branch. Form This life can be found in all the study sites with a range of closure 0.32 to $5.86 \%$. Form branched colonies are colonies form the most rapidly growing. Grew at an average speed is $10 \mathrm{~cm} /$ tahun (Tomascik, 1997). Colonies form massive colonies with the slowest growth of $4.3 \mathrm{~cm}$ / year whereas foliose colonies shaped (shaped like leaf) $5 \mathrm{~cm} /$ year (Barnes \& Rupert, 1997). However, the form branched colonies are easily broken or damaged due to environmental stresses such as hard and big waves. Mass death that often occurs in the types of branching corals with a form factor that can maintain a high level of diversity of coral reefs due to death The chamber prevent monopoly grew by these species. A massive colony forms colonies resistant to wave action. Besides, this form of colony can adapt to almost any condition environment. For the NonAcropora corals that form of life found is branching (branching), massive, creeping (encrusting), submasif and sheet shaped like leaves (foliose). Submasif colonies can be found in all study sites with closure of a relatively small range of $0.12-10.38 \%$. Form colonies submasif is like branching colonies but short branching, denser and larger. Form colonies that submasif compact enough cause colony form is quite resistant to the effects physical. Slowest colony growth is massive but this colony form relatively more resistant to physical environmental influences such as waves, droughts and changes in salinity and temperature compared with other colony forms. Massive coral cover ranged from 2.48 to $24.24 \%$. Form colonies that are present in all other locations are creeping (Encrusting). In some places large enough percent closure is on station 6 a depth of 6 meters at $36.20 \%$ and station 4 at a depth of 58 meters of $21.36 \%$. At a depth of 6 meters possibility sun began reduced. To take advantage of the sun as much as possible the reef will koralitnya expand horizontally. Thus the coral surface shaped edging (foliose). At 5 feet container, it was assumed sunshine sufficient for the needs of the reef. But the form is quite resistant to creeps environmental pressures on the reef because the wall is compact and easy broke. At 5 feet container of human activities on the container is greater than 7 meter because it is relatively easy to reach. Activities include catching ornamental fish and coral collection. The activities of this causing possible damage to the reef are also getting bigger. At 5 container meter waves pounding effect is also larger than the container 7 meters. Biggest closure of each study site is abiotic components consisting of rubble, water (water), sand (sand), sediment (silt) and rock (rock). Sediment (silt) and rock (rock) dominate almost any location. On sediment (silt) is the highest station 3 at 6 meter container that is $37.68 \%$. Next is the 6 container 6 meter station at $34.20 \%$ and container station 45 meter is $30.44 \%$. While on the rocks (rock) sequentially highest 5 feet 9 container station is $38.22 \%$, container 10 Station 5 meters at $35.14 \%$ and 5 container station 5 meters of $32.66 \%$. Based on observations Closing the magnitude of sediment (silt) and rock (rock) is the main caused by the influx of sediment from the river to the sea to continue to occur constantly. In addition, it can be caused by the movement of currents around the island The. Power flow from the South China Sea in the north of the island is greater than from the Java Sea in the south of the island. Flows from the north carrying sand substrate (sand) and sedimentation entering (inflow) to the sea comes from the mainland led to the deposition in the Island Lemukutan and surroundings especially at point 8 , which has a regional station extensive rock solid than other parts. Sand teredapkan 
this is not all swept back from the north caused the difference in the power flow in the area. At this station there is also a makroalgae closing high with a value of $54.32 \%$, this is due to the character babatuan many islands so dense algae can grow with good.

\section{Types of Reefs}

Research conducted in June 2012 at the Island Lemukutan and surrounding areas in 35 different types of coral that get included in the Family 7 and 2 Order. For full results can be seen in Table 7 as follows:

Table 7. Coral species found on the island and surrounding Lemukutan.

Type of genus Acropora is the most commonly found type 12

\section{Acropora}

Genus Acropora has the most abundant species, 10 of the 368 members of the type (Tomascik et al., 1997). According Suharsono (1996) in Indonesia there are about 150 species of Acropora, spread throughout Indonesia. Because many species Acropora genus has a framework is not thick making it possible to grow and evolve with fast. In addition, the genus Acropora has koralit koralit axial and radial. At koralit axial polyp grows sideways koralit called radial. In development will be koralit koralit radial axial, and will grow similarly koralit new radial, so that Acropora growth becomes faster. Genus Montipora get the No. 2 after the Genus Acropora. On study site was found 6 species of the genus Montipora. Around the world around 200 species which is the second highest after the Acropora species. Form colonies of Montipora vary from creeping (encrusting) until massive, there is also shaped like a sheet (foliose). On the type of Helliopora coerulea also found in some point of observation stations. Waters in the study area were occur damage caused by physical factors, namely sedementasi. Pocillopora eudouxi is a type that can be found in all locations research. Submasif to form colonies are clearly visible verrucae. Verrucae are small protrusions that cover the coral colonies. Growth Pocillopora depend on wave motion and light intensity. Colony Eudouxi Pocillopora branches tend to grow thick on nutrient-rich environment. Conversely in waters deep enough or the lagoon will grow branching Pocillopora eudouxi thinner. Pocillopora eudouxi tends to grow as the first colony in an area or location and will provide a good environment for the growth of coral colonies other. The types of coral that were found on the island and surrounding Lemukutan is a common coral species found in Indonesia. A reef area coral species may have different coral species other regions reefs. The existence of the reef will be influenced in part by environmental conditions. Differences in sedimentation rate, flow velocity, type growth coral can cause difference of species encountered as coral possessed survival rates for each environment (Tolerance limit).

\section{CONCLUSION}

The conclusion of this study is :

1. The condition of coral reefs in the marine protected area of the island 5 , have live coral cover (lifeform) with categories ranging from poor up well. Live coral cover (lifeform) with the highestpercentage of $69.00 \%$ in small stylist station at a depth of 6 meters, 
while with the lowest percentage of $13.82 \%$ in covering the station depth of 7 meters.

2. Research in Marine Protected Areas of the 5 islands, the District Bengkayang obtained 35 coral species included in the Family 7. Type the hard coral genus Acropora dominated with 12 species and Montipora genus with 6 species.

Suggestion

Damage caused to the marine protected area of 5 islands, if continued would lead to the loss of marine resources important. So that the necessary corrective measures and environmental conservation coral reefs and surrounding Lemukutan Island. Conducted monitoring activities periodically to determine the health of coral reef island Lemukutan and surrounding areas. Good condition can increase the potential for marine resources. Moreover, it can be used as a marine tourism.

\section{REFERENCES}

Barnes, R. D. and E.E. Rupert. 1997. Invertebrata zoology 6th edition. Sanders college publisihing. Fort Wort.

Burke L., E. Selig, and M. Spalding. 2001. Terumbu Karang Yang Terancam Di Asia Tenggara (Ringkasan untuk Indonesia). World Resources Institute. Amerika Serikat. Castro, P. and M.E. Huber. 2000. Marine Biology 3rd edition. McGraw Hill Book Company. Boston.

Dahuri, R. 2003. Keanekragaman Hayati Laut. PT. Gramedia Pustaka Utama, Jakarta.

Dinas Kelautan dan Perikanan Provinsi Kalimantan Barat. 2005. Master PlanKawasan Konservasi Laut Daerah (Laporan Akhir) Kabupaten Bengkayang (Buku 1: Pengelolaan KKLD), Pontianak.12

English, S., C. Wilkinson and V. Baker. 1994. Survey Manual for Tropical Marine Resources. Australian Institut of Marine Sciences. Townsville.

Gomez, E.D. dan H.T. Yap. 1988. Monitoring Reef Condition dalam Coral Reef Management Handbook, 2nd edition. UNESCO Regional Office for Science and Technology for South Asia. Jakarta.

Johan, O. 2003. Karakteristik Biologi Karang. Makalah Training Course. Yayasan Terangi. Jakarta.

Nontji, A. 1984. Peranan zooxanthellae dalam ekosistem Terumbu karang. Oseana. Volume IX nomor 3.

Nybakken, J.W. and M.P.Bertness. 2005. Marine biology an ecological approach 6thed. San Francisco : Person Education.

Odum, E.P. 1993. Dasar-dasar Ekologi. Terjemahan Tjahjono Samingan. Edisi Ketiga. Yogyakarta: Gadjah Mada University Press.

Phongsuwan, N. and H. Chansang. 1992. Assessment of Coral Communities in the Andaman Sea (Thailand). Proceedings of the 7th Coral Reef Symposium, Guam. pp : 114-121

Sudiono, G. 2008. Analisis pengelolaan terumbu karang pada kawasan konservasi laut daerah (KKLD) pulau randayan dan sekitarnya Kabupaten bengkayang provinsi kalimantan barat. Thesis. Sekolah Pascasarjana Program Magister Ilmu Lingkungan. 
Universitas Diponegoro.

Suharsono, 2008. Jenis-Jenis Karang di Indonesia. Jakarta: Coremap Program LIPI.

Sukmara, A., A.J. Siahainenia \& C. Rotinsulu. 2002. Panduan Pemantauan Terumbu Karang Berbasis Masyarakat dengan Metode Manta Tow.

Departemen Kelautan dan Perikanan \& Coastal Resources Center University of Rhode Island, Jakarta.

Timotius, S. 2003. Biologi Terumbu Karang. Makalah Training Course. Yayasan Terangi. Jakarta.

Tomascik, T.,A.J. Mah, A. Notji, and M.K. Moosa. 1997. The ecology of Indonesian seas part I. Periplus edition.

Veron, J.E.N. 2000. Corals of The World, vol 1, 2, 3. The Australian Institute of Marine Science. Queensland. 